\title{
Trajetórias de pesquisa e experiências educativas nas Ciências da Terra
}

O volume 10 de Terrce Didatica dá início a ambiciosa ampliação do projeto editorial, em busca de fortalecê-la como revista científica nacional. De 2014 em diante publicaremos três edições por ano, sempre abordando temas científicos em Ciências da Terra.

O terceiro número (dezembro), reunirá comunicações do evento Interfaces Geociências e Ensino: 40 anos de experiências (1973-2013), realizado na Unicamp, entre 23 e 24 de agosto passado. A comemoração dos 40 anos de uma bela trajetória de atividades iluminou as etapas e os resultados mais relevantes. Os artigos consistem de depoimentos sobre a história e efeitos do percurso de um grupo inicial, que se formou na USP e cresceu na Unicamp.

Boas ideias ultrapassam quem as criou e ganham vida própria.

A revista é um periódico eletrônico de acesso livre que estimula o intercâmbio de materiais didáticos e recursos educativos de Ciências da Terra. A distribuição, nacional e internacional, envolve exemplares impressos e - como forma dominante de acesso - da edição eletrônica. Se a versão digital tem, em seu favor, o acesso fácil nos cantos mais remotos do planeta, é inegável o prazer da leitura do papel impresso com boa qualidade. Só o tempo dirá qual alternativa sobreviverá; ou se as duas podem se manter.

É evidente o papel estratégico das revistas de acesso livre, em contraposição a periódicos "comerciais" que tendem a concentrar o conhecimento e a informação relevante gerados nas universidades e instituições de pesquisa. O "comércio" do conhecimento tem sérias implicações. Não raro os preços das revistas do exterior são inacessíveis a estudantes e profissionais; seria um modo velado de privatizar recursos públicos, porque boa parte das descobertas origina-se do apoio de órgãos públicos de fomento. Em Sobrecultura, de Ciência Hoje (DEZEMBro DE 2013, SBPC. URL: http://cienciahoje.uol.com.br/ revista-ch/2013/310/produtividade-academica),
Ivan Domingues assinala que cientistas prestigiados se insurgem "contra a visão do conhecimento como negócio e a produção acelerada", enquanto Simon Schwartzman destaca a excessiva importância atribuída aos indicadores de produção, especialmente quando "os indicadores se tornam mais importantes do que aquilo que precisam indicar". Existe grave risco: "se o que importa é o número de publicações e citações, e não o que está sendo publicado ou citado, isso abre a porta para manipular os indicadores...".

Esta edição reune temas inspiradores e experiências educativas. Os artigos iniciais são "paleontológicos": o problema da preservação de tecidos moles em fósseis, e um experimento de difusão científica de Paleontologia em Sergipe. Os temas que se seguem são uma oficina didática sobre maquete de relevo em Barra do Garças, Mato Grosso; alguns exemplos e bases de aplicação prática da aerogamaespectrometria em mapeamento geológico e uma análise de contribuições sobre o Pré-Cambriano de São Paulo, até 1955. Este número se completa com uma tradução valiosa sobre o conceito de Tempo Geológico e suas implicações.

O esforço coordenado da revista em contribuir com a difusão da produção educacional relevante procura apoiar uma tarefa urgente: o movimento geral em busca do aprimoramento da qualidade da divulgação geocientífica feita no País. Essas iniciativas ajudam a aumentar o interesse dos jovens e adultos pela ciência.

Para consolidar revistas como esta, é preciso contar com mais verbas, além do apoio institucional da Unicamp. Continuamos buscando apoio e patrocínio de empresas, fundações, órgãos de governo e pessoas físicas que aceitem doar ou contribuir de algum modo para a revista, com excelente receptividade. A todos que apoiam Terrae Didatica, dedicamos caloroso agradecimento.

Os editores Campinas, abril de 2014. 